This is an author produced version of a paper published in Tropical Animal Health and Production.

This paper has been peer-reviewed but may not include the final publisher proof-corrections or pagination.

Citation for the published paper:

Aziz-ul-Rahman, Jonas Johansson Wensman, Muhammad Abubakar, Muhammad Zubair Shabbir, Paul Rossiter. (2018) Peste des petits ruminants in wild ungulates. Tropical Animal Health and Production. Volume: 50, Number: 8, pp 1815-1819.

https://doi.org/10.1007/s11250-018-1623-6

Access to the published version may require journal subscription.

Published with permission from: Springer.

Standard set statement from the publisher:

"The final publication is available at Springer via https://doi.org/10.1007/s11250-0181623-6"

Epsilon Open Archive http://epsilon.slu.se 


\section{Peste des Petitis Ruminants in Wild Ungulates}

Aziz-ul-Rahman ${ }^{1 * \#}$, Jonas Johansson Wensman ${ }^{2 *}$, Muhammad Abubakar ${ }^{3}$, Muhammad Zubair Shabbir ${ }^{4}$ and Paul Rossiter ${ }^{5}$

${ }^{1}$ Department of Microbiology, University of Veterinary and Animal Sciences Lahore 54600, Pakistan. https://orcid.org/0000-0002-3342-4462

${ }^{2}$ Department of Clinical Sciences, Swedish University of Agricultural Sciences, P.O. Box 7054, 75007 Uppsala, Sweden. https://orcid.org/0000-0002-6957-7110

${ }^{3}$ National Veterinary Laboratories, Park Road, Islamabad 44000, Pakistan.

${ }^{4}$ Quality Operation Laboratory, University of Veterinary and Animal Sciences Lahore 54600, Pakistan. https://orcid.org/0000-0002-3562-007X

54, Urafiki Lane, Muthaiga, P.O. Box 3008700100 Nairobi, Kenya.

*Authors with equal contribution

\#Corresponding author

Cell \# +92334-6988287

Email:drazizangel@gmail.com

https://orcid.org/0000-0002-3342-4462

ABSTRACT

Peste des petits ruminants (PPR) is a contagious viral disease of domestic small ruminants. It also affects wild ungulates but there are comparatively few studies of the incidence of natural infection, clinical signs and pathology, and confirmation of the virus, and in these species. In this article, we list the wild ungulates in which PPRV infection has been confirmed and summarize available information about the presentation of the disease, its identification, and impact of virus on wildlife populations. Considering recent reports of outbreaks by the World Organization for Animal Health (OIE), it is important to understand the transmission of this disease within wildlife populations in PPR endemic regions.

Keywords: PPR virus, Wild ungulates, Genetic depletion, Interspecies transmission 


\section{INTRODUCTION}

Peste des petits ruminants virus (PPRV) is the cause of peste des petits ruminants (PPR), a contagious, transboundary disease of small domestic ruminants and some wild ungulates (Kinne et al. 2010; Munir et al. 2012). Because of its impact on small ruminants, and its similarity to the recently eradicated Rinderpest virus, the World Organization for Animal Health (OIE) and the Food and Agricultural Organization (FAO) launched a joint program to eradicate PPRV by 2030 (FAO 2015). PPR is also a threat to wildlife and therefore to the conservation of endangered species (Munir 2014).

It was first assumed that PPRV only affected sheep and goats (Lefevre and Diallo 1990), but it has since been observed clinically and pathologically in a wider range of species and confirmed diagnostically either directly through detection of virus, viral antigens or specific viral RNA or indirectly through detection of antibodies in wild ruminants (Kinne et al. 2010); cattle, domestic buffaloes (Balamurugan et al. 2012a), yaks (Abubakar et al. 2015), camels (Kwiatek et al. 2011), Asiatic lion (Balamurugan et al. 2012b) and dogs (Ratta et al. 2016). Some wild ruminant species are at high-risk from PPRV (Rossiter 2008) and domestic small ruminants most likely play a role in the spread of the virus to them. However, disease may also be disseminated from infected wildlife to other susceptible wildlife. Most of the available data on the disease and on PPRV are from domestic small ruminants, and data from wildlife is more limited. Host and virus-related factors in the spread of PPRV infection need better understanding if PPR is to be eradicated locally and globally. This brief report lists the known wild ungulates in which PPRV infection has been confirmed and highlights some key emerging issues regarding this infection in these species. The term "wild" covers free-ranging, semi-captive and captive 
animals. In the text species are referred to by their English or colloquial names, with their Latin binomials being given in table 1 .

\section{VIRUS TRANSMISSION IN WILD SMALL RUMINANTS}

In many areas where PPR is endemic, domestic animals intermingle with wildlife, allowing interspecies transmission of PPRV during grazing and at water sources (Banyard and Parida 2015). Abubakar et al (2011) speculated that an outbreak of PPR in Sindh ibex was due to spillover of virus from a recent outbreak of PPR in nearby domestic small ruminants. Similar spillovers to wild hosts are believed to have occurred in Tibet (Bao et al. 2011) and in the Ngorongoro Conservation Area in northern Tanzania (Mahapatra et al. 2015).

From an epidemiological point of view, there is potential for interspecies transmission

between wild species and from wild species back to domestic ruminants, but the dynamics of such transmission mechanisms are uncertain. The transfer of wildlife to zoological collections and seasonal migration of animals are two possibilities for disease spread over significant distances and across country borders (Mallon and Kingswood 2001).

\section{CLINICAL AND PATHOLOGICAL PRESENTATION}

The clinical presentation of PPRV is wild ungulates is essentially the same as in domestic small ruminants. Initial involvement of the respiratory system causes lacrimation, nasal and ocular discharges (Bao et al. 2011; Abubakar et al. 2011; Hoffmann et al. 2012) which may lead to crusts forming over the nostrils and lip commissure (reported in antelopes; Kinne et al. 2010). Subsequent involvement of the alimentary tract epithelia causes cheesy necrotic material on the gums (reported in ibex; Abubakar et al. 2011) and erosions of the oral cavity membranes (reported in gazelle; Sharawi et al. 2010). Unilateral corneal opacity has also been observed in 
gazelle (Abu-Elzein et al. 2004). Death from respiratory arrest has been reported in gazelle, ibex, gemsbok and laristan sheep (Furley et al. 1987; Abu-Elzein et al. 2004).

The severity of PPR infection (Bao et al. 2011) is seen from pathological changes in different visceral organs, including syncytia and multifocal hepatocellular coagulation via necrosis (Kinne et al. 2010), and postmortem histopathology was used to confirm PPRV infection in Dorcas and Thompson's gazelles (Furley et al. 1987). Similar features are found in infected small domestic ruminants (Brown et al. 1991).

\section{IMPACT OF PPR ON GENETIC DEPLETION}

According to the International Union for Conservation of Nature and Natural Resources (IUCN), rare species are at risk of genetic depletion when outbreaks of serious disease, such as PPR, lead to high mortality (Osofsky 2005). The global attention and response to the recent high mortalities of free-ranging Saiga antelope, including one outbreak confirmed to be caused by PPRV in Mongolia where at least $10 \%$ of the population was depleted (FAO 2017), is a clear example of the potential impact of PPRV on rare species. Rare wildlife kept and raised under captive or semi-captive conditions for conservation purposes are also at risk, as seen in the $70 \%$ mortality reported for Nubian ibex in an Israeli zoo (OIE 2017a). Implementation of quarantine measures and transfer of only seronegative animals should reduce the incidence of such events (Rossiter 2008) but global eradication offers a longer lasting solution.

\section{CONCLUDING REMARKS}

In this article, we have briefly summarized the current knowledge on PPRV occurrence in wild ungulates and listed (Table 1) those wild species of in which disease has been recorded and

confirmed, some of which are endangered and at elevated risk of genetic losses if infected by PPRV. The list can be expected to change: growing as more species are found to be susceptible 
to PPRV, altering as the classification of closely related host species and sub-species is refined, and as new and more accurate information about PPRV infection in these species becomes available.

To date there is no evidence that wild species play a different epidemiological role in PPR to that played in the past by wild species infected by rinderpest virus. Wildlife proved incapable of permanently maintaining rinderpest virus but was valuable clinical and serological sentinels for virus in nearby cattle, and more study is required to establish the contribution wild species can play as sentinels during the eradication of PPRV (Couacy-Hymann et al. 2005). Additional study is also needed on the impact of PPRV on the genetic diversification capacity of wild host species, and on the transmission pathways for PPRV into and within wild populations. The existing evidence of the severity of PPRV infection in endangered wildlife that associate with infected small ruminants, is compelling support for global eradication of the virus and for better control strategies targeted at these wildlife-livestock interfaces.

\section{ACKNOWLEDGEMENTS}

JJW is supported by the Swedish Research Council for PPR research (Grant no. SRC 348-2013-6402 and SRC 348-2014-4293). All authors are highly indebted to Dr. Muhammad Munir (The Pirbright Institute, UK) for his sincere guidance and Dr Mohammed Afzal for his permission to include the data on blackbuck.

\section{CONFLICT OF INTERESTS}

The authors declare that they have no competing interests.

\section{AUTHOR'S CONTRIBUTIONS}


AR, JJW and MA initiated the idea and drafted the skeleton of the manuscript. MZS, JJW and AR gave technical guidance and support. JJW, MZS and PBR provided input, guidance, support and editing of the manuscript. All authors approved the final manuscript.

\section{REFERENCES}

Abubakar, M., Rajput, Z.I., Arshed, M.J., Sarwar, G. and Ali, Q., 2011. Evidence of peste des petits ruminants virus (PPRV) infection in Sindh Ibex (Capra aegagrus blythi) in Pakistan as confirmed by detection of antigen and antibody, Tropical Animal Health and Production, 43, 745-747

Abubakar, M., Manzoor, S., Khan, E-ul.H., Manzoor, H., Afzal. M., Ali, Q., Wensman, J.J., Munir, M., 2015. Serological evidence of peste des petits ruminants in yak, Pakistan, In: proceeding of $10^{\text {th }}$ International Congress of Veterinary Virology, $9^{\text {th }}$ Annual Meeting of EPIZONE, Le Corum, Montpellier, France, $31^{\text {st }}$ August $-3^{\text {rd }}$ September 2015, p. 73. ESVV.

Abu-Elzein, E.M., Housawi, F.M., Bashareek, Y., Gameel, A.A., Al-Afaleq, A.I. and Anderson, E., 2004. Severe PPR infection in gazelles kept under semi-free-range conditions, Journal of Veterinary Medicines B, Infectious and Veterinary Public Health, 51, 68-71

Balamurugan, V., Krishnamoorthy, P., Veeregowda, B.M., Sen, A., Rajak, K.K., Bhanuprakash, V., Gajendragad, M.R. and Prabhudas, K., 2012a. Sero-prevalence of Peste des petits ruminants in cattle and buffaloes from Southern Peninsular India, Tropical Animal Health and Production, 44(2), 301-306

Balamurugan. V., Sen, A. and Venkatesan, G., 2012b. Peste des petits ruminants virus detected in tissues from an Asiatic lion (Panthera leo persica) belongs to Asian lineage IV, Journal of Veterinary Science, 13, 203-206. doi:10.4142/jvs.2012.13.2.203

Banyard, A.C. and Parida, S., 2015. Molecular Epidemiology of Peste des Petits Ruminants Virus, Peste des Petits Ruminants Virus: Springer, 69-93

Bao, J., Wang, Z., Li, L., Wu, X., Sang, P., Wu, G., Ding, G., Suo, L., Liu, C., Wang, J., Zhao, W., Li, L. and Qi, L., 2011. Detection and genetic characterization of peste des petits ruminants virus in free-living bharals (Pseudois nayaur) in Tibet China, Research in Veterinary Sciences, 90, 238-240

Bello, A.M., Lawal, J.R., Dauda, J., Wakil, Y., Lekko, Y.M., Mshellia, E.S., Ezema, K.U., Balami, S.Y., Waziri, I. and Mani, A.U., 2016. Research for peste des petits ruminants (PPR) virus antibodies in goats, sheep and gazelle from Bauchi and Gombe States, north eastern Nigeria, Direct Research Journal Agriculture and Food Science, 4(8), 193-8 
Brown, C.C., Mariner, J.C. and Olander, J.H., 1991. An immunohistochemical study of the pneumonia caused by peste des petits ruminants virus, Veterinary Pathology, 28, 166170

Couacy-Hymann, E., Bodjo, C., Danho, T., Libeau, G. and Diallo, A. 2005. Surveillance of wildlife as a tool for monitoring rinderpest and peste des petits ruminants in West Africa, Revue Scientifique et Technique, 24, 869-877

FAO, 2015. Prevention and control of transboundary animal diseases. Report of the FAO Expert Consultation on the Emergency Prevention System (EMPRES) for Transboundary Animal and Plant Pests and Diseases (Livestock Diseases Programme).

FAO. 2017. News archive on the alarm as lethal plague detected among rare Mongolian antelope. . http://www.fao.org/news/story/en/item/463932/icode/. Accessed 27 Jan 2017

Furley, C.W., Taylor, W.P. and Obi, T.U., 1987. An outbreak of peste des petits ruminants in a zoological collection, Veterinary Record, 121, 443-447

Gur, S. and Albayrak, H., 2010. Seroprevalence of peste des petits ruminants (PPR) in goitered gazelle (Gazella subgutturosa subgutturosa) in Turkey, Journal of Wildlife Disease, 46, 673-677

Hamdy, F.M. and Dardiri, A.H., 1976. Response of white-tailed deer to infection with peste des petits ruminants virus, Journal of Wildlife Disease, 12, 516-522

Hoffmann, B., Wiesner, H., Maltzan, J., Mustefa, R., Eschbaumer, M., Arif, F.A. and Beer, M., 2012. Fatalities in wild goats in Kurdistan associated with Peste des Petits Ruminants virus, Transboundary and Emerging Disease, 59, 173-176

Intisar, K.S., Ali, Y.H., Haj, M.A., Sahar, M.A.T., Shaza, M.M., Baraa, A.M., Ishag, O.M., Nouri, Y.M., Taha, K.M., Nada, E.M. and Ahmed, A.M., 2017. Peste des petits ruminants infection in domestic ruminants in Sudan, Tropical Animal Health and Production, 49(4), 747-754

Jaisree, S., Aravindhbabu, R.P., Roy, P. and Jayathangaraj, M.G., 2018. Fatal peste des petits ruminants disease in Chowsingha, Transboundary and emerging diseases, 65, e198-e201. http://onlinelibrary.wiley.com/doi/10.1111/tbed.12694/epdf

Kinne, J., Kreutzer, R., Kreutzer, M., Wernery, U. and Wohlsein, P., 2010. Peste des petits ruminants in Arabian wildlife, Epidemiology and Infection, 138, 1211-1214

Kwiatek, O., Ali, Y.H., Saeed, I.K., Khalafalla, A.I., Mohamed, O.I., Obeida, A.A., Abdelrahman, M.B., Osman, H.M., Taha, K.M., Abbas, Z., El Harrak, M., Lhor, Y., Diallo, A., Lancelot, R., Albina, E. and Libeau, G., 2011. Asian lineage of peste des petits ruminants virus in Africa. Emerging Infection Disease, 17, 1223-1231 
Lefevre, P.C. and Diallo, A., 1990. Peste des petits ruminants virus. Revue Scientifique et Technique Office International of Epizootics, 9, 951-965

Li, J., Li, L., Wu, X., Liu, F., Zou, Y., Wang, Q., Liu, C., Bao, J., Wang, W., Ma, W. and Lin, H, 2017. Diagnosis of Peste des Petits Ruminants in Wild and Domestic Animals in Xinjiang, China, 2013-2016, Transboundary and Emerging Diseases, 64, e43-e47

Mahapatra, M., Sayalel, K. and Muniraju M., 2015. Spillover of peste des petits ruminants virus from domestic to wild ruminants in the Serengeti ecosystem, Tanzania, Emerging Infectious Diseases, 21, 2230-2234

Mallon, D.P. and Kingswood, S.P., 2001. Antelopes. Part IV. North Africa, the Middle East and Asia. Global survey and regional action plans. SSC Antelope Specialist Group, IUCN, Cambridge.

Marashi, M., Masoudi, S., Moghadam, M.K., Modirrousta, H., Marashi, M., Parvizifar, M., Dargi, M., Saljooghian, M., Homan, F., Hoffmann, B. and Schulz, C., 2017. Peste des Petits Ruminants Virus in Vulnerable Wild Small Ruminants, Iran, 2014-2016. Emerging Infectious Diseases, 23(4), 704

Munir, M., 2014. Role of wild small ruminants in the epidemiology of peste des petits ruminants, Transboundary and Emerging Diseases, 61(5), 411-424

Munir, M., Zohari, S. and Berg, M., 2012. Molecular Biology and Pathogenesis of Peste des Petits Ruminants Virus, 1stedn. pp. 151. Springer, Germany

Office International des Epizooties (OIE). 2017a. World Animal Health Information System. In: Weekly Animal Disease Service Global Report. http://www.oie.int/wahis_2/public/wahid.php/Reviewreport/Review?reportid=22225. Accessed 10 Jan 2017

Office International des Epizooties (OIE). 2017b. World Animal Health Information System. In: Weekly Animal Disease Service Global Report. 2017. http://www.oie.int/wahis_2/public/wahid.php/Reviewreport/Review?reportid=22395. Accessed 18 Jan 2017

Osofsky, S.A. ed., 2005. Conservation and Development Interventions at the Wildlife/livestock Interface: Implications for Wildlife, Livestock and Human Health: Proceedings of the Southern and East African Experts Panel on Designing Successful Conservation and Development Interventions at the Wildlife/Livestock Interface: Implications for Wildlife, Livestock and Human Health, AHEAD (Animal Health for the Environment And Development) Forum, IUCN Vth World Parks Congress, Durban, South Africa, 14th and 15th September 2003 (No. 30). IUCN 
Ogunsanmi, A.O., Awe, E.O., Obi, T.U. and Taiwo, V.O., 2003. Peste des petits ruminants (PPRV) virus antibodies in African Grey Duiker (Sylvicapra grimma), African Journal of Agriculture Research, 6, 59-61

Ratta, B., Pokhriyal, M., Singh, S.K., Kumar, A., Saxena, M. and Sharma, B., 2016. Detection of Peste des Petits Ruminants Virus (PPRV) Genome from Nasal Swabs of Dogs, Current microbiology, 73, 99-103

Rossiter, P., 2008. "Peste des Petits Ruminants" in edited by Williams, E.S. and Barker, I.K. Infectious Diseases of Wild Mammals. John Wiley \& Sons

Sharawi, S.S., Yousef, M.R., Al-Hofufy, A.N. and Al-Blowi, M.H., 2010. Isolation, serological and real time PCR diagnosis of Peste des Petites Ruminants virus in naturally exposed Arabian Gazelle in Saudi Arabia, Veterinary World, 1(11), 489-494

Xia, J., Zheng, X.G., Adili, G.Z., Wei, Y.R., Ma, W.G., Xue, X.M., Mi, X.Y., Yi, Z., Chen, S.J., Du, W., Muhan, M., Duhaxi, C., Han, T., Gudai, B. and Huang, J., 2016. Sequence analysis of peste des petits ruminants virus from ibexes in Xinjiang, China, Genetics in $\begin{array}{lllll}\text { Molecular } & \text { Research, } & 15 & \text { (2), } & \text { gmr.15027783. }\end{array}$ http://dx.doi.org/10.4238/gmr.15027783

Zhou, X.Y., Wang, Y., Zhu, J., Miao, Q.H., Zhu, L.Q., Zhan, S.H., Wang, G.J. and Liu, G.Q., 2018. First report of peste des petits ruminants virus lineage II in Hydropotes inermis, China, Transboundary and Emerging Diseases, 65, e205-e209 http://onlinelibrary.wiley.com/doi/10.1111/tbed.12683/epdf

Zhu, Z., Zhang, X., Adili, G., Huang, J., Du, X., Zhang, X. and Xue, Q., 2016. Genetic Characterization of a Novel Mutant of Peste des Petits Ruminants Virus Isolated from Capra ibex in China during 2015, BioMed Research International, 2016, 7632769 
Table 1: Evidence of natural or experimental PPRV infection in wild ungulates

\begin{tabular}{|c|c|c|c|}
\hline Common Name & Scientific Name & Country & References \\
\hline \multicolumn{4}{|c|}{ Wild species from which PPR virus has been isolated in cell culture: } \\
\hline Water deer* & Hydropotes inermis & China & Zhou et al. 2018 \\
\hline Wild Ibex* & Capra ibex & China & Zhu et al. 2016 \\
\hline Bushbuck & Tragelaphus scriptus & UAE & Kinne et al. 2010 \\
\hline Springbuck & Antidorcas marsupialis & UAE & Kinne et al. 2010 \\
\hline Arabian gazelle & Gazella gazelle & UAE & Kinne et al. 2010 \\
\hline Arabian Mountain gazelle & Gazella gazella cora & UAE & Kinne et al. 2010 \\
\hline Dorcas gazelle* & Gazella dorcas & UAE: KSA & Furley et al. 1987; Abu-Elzein et al. 2004 \\
\hline Thomson's gazelle* & Eudorcas thomsonii & KSA & Abu-Elzein et al. 2004 \\
\hline Goitered gazelle & Gazella subgutturosa & UAE & Kinne et al. 2010 \\
\hline Impala & Aepyceros melampus & UAE & Kinne et al. 2010 \\
\hline Gemsbok & Oryx gazelle & UAE & Furley et al. 1987 \\
\hline Afghan Markhor Goat & Capra falconeri & UAE & Kinne et al. 2010 \\
\hline Nubian Ibex & Capra nubiana & UAE & Furley et al. 1987 \\
\hline \multicolumn{4}{|c|}{ Wild species from which PPR virus antigen or nucleic acid has been identified using ELISA/PCR/Sequencing: } \\
\hline Water deer* & Hydropotes inermis & China & Zhou et al. 2018 \\
\hline Chowsingha & Tetracerus quadricornis & India & Jaisree et al. 2018 \\
\hline African buffalo* & Syncerus caffer & Côte d'Ivoire & Couacy-Hymann et al. 2005 \\
\hline Saiga antelope & Saiga tatarica & Mongolia & FAO 2017; OIE 2017b \\
\hline Blackbuck & Antilope cervicapra & Pakistan & FAO-UN Project (GCP/PAK/127/USA) 2017 \\
\hline Goitered gazelle & Gazella subgutturosa & Mongolia: China & OIE 2017b; Li et al. 2017 \\
\hline Grant's gazelle & Nanger granti & Tanzania & Mahapatra et al. 2015 \\
\hline Kob & Kobus kob & Côte d'Ivoire & Couacy-Hymann et al. 2005 \\
\hline Nile lechwe & Kobus megaceros & Sudan & OIE-WAHIS 2008 \\
\hline Defassa waterbuck & Kobus ellipsiprymnus & Côte d'Ivoire & Couacy-Hymann et al. 2005 \\
\hline Bubal hartebeest & Alcelaphus buselaphus & Côte d'Ivoire & Couacy-Hymann et al. 2005 \\
\hline Wild goat & Capra aegagrus & Kurdistan: Iran & Hoffmann et al. 2012; Marashi et al. 2017 \\
\hline Sindh ibex & Capra aegagrus blythi & Pakistan & Abubakar et al. 2011 \\
\hline Siberian ibex & Capra sibirica & Mongolia & OIE 2017b \\
\hline
\end{tabular}




\begin{tabular}{|l|l|l|l|}
\hline Wild ibex* & Capra ibex & China & Xia et al. 2016; Zhu et al. 2016; Li et al. 2017 \\
\hline Nubian ibex & Capra nubiana & UAE: Israel & Kinne et al. 2010; OIE 2017a \\
\hline Bharal* & Pseudois nayaur & China & Bao et al. 2011 \\
\hline Argali & Ovis ammon & China & Li et al. 2017 \\
\hline Wild species in which PPRV antibodies have been found using ELISA: & Côte d'Ivoire; Tanzania & $\begin{array}{l}\text { Couacy-Hymann et al. 2005; Mahapatra et al. } \\
\text { 2015 }\end{array}$ \\
\hline African buffalo* & Syncerus caffer & Gur and Albayrak 2010 \\
\hline Goitered gazelle & Gazella subgutturosa & Turkey & Intisar et al. 2017; Bello et al. 2016 \\
\hline Dorcas Gazelle & Gazella dorcas & Sudan; Nigeria & Mahapatra et al. 2015 \\
\hline Grant's gazelle & Nanger granti & Tanzania & Ogunsanmi et al. 2003 \\
\hline African grey duiker & Sylvicapra grimmia & Nigeria & Couacy-Hymann et al. 2005 \\
\hline Defassa waterbuck* & Kobus ellipsiprymmus & Côte d'Ivoire & Mahapatra et al. 2015 \\
\hline Impala & Aepyceros melampus & Tanzania & Mahapatra et al. 2015 \\
\hline Blue Wildebeest & Connochaetes taurinus & Tanzania & Bao et al. 2011 \\
\hline Bharal* & Pseudois nayaur & China & Abu-Elzein et al. 2004 \\
\hline Wild species in which PPRV antibodies have been found using cross-serum neutralization tests (CSNT): \\
\hline Dorcas gazelle* & Gazella dorcas & KSA & Abu-Elzein et al. 2004 \\
\hline Thomson's gazelle* & Eudorcas thomsonii & KSA & Hamdy and Dardiri 1976 \\
\hline Wild species infected experimentally with PPRV: & Odocoileus virginianus & USA & Uan \\
\hline White Tailed deer &
\end{tabular}

$*=$ Species for which PPR infection was found by more than one method

KSA, Kingdom of Saudi Arabia: UAE, United Arab Emirates: USA, United States of America. 